\title{
PENGEMBANGAN BAHAN AJAR UNTUK MENUMBUHKAN NILAI KARAKTER PEDULI LINGKUNGAN PADA SISWA KELAS IV SEKOLAH DASAR
}

\author{
Henry Januar Saputra, Nur Isti Faizah. \\ Fakultas Ilmu Pendidikan, Universitas PGRI Semarang \\ e-mail : cahsmandam@gmail.com
}

\begin{abstract}
This study was conducted using ADDIE method development procedures with steps include Analysis, Design, Development, Implementation and Evaluation. The research was conducted in SDN Sendangmulyo 03 Semarang. The research subjects in this study were 34 fourth grade students. The data collected in this study is data and data media expert subject matter experts and product testing results data. The average results of students' prior to using EE teaching materials amounting to 64.12 while the average student learning outcomes after the use of teaching materials PLH of 90.51. Then, from the observation of environmental care character on the student obtained the result "Very Good" with an average score of 19. It shows a decent EE instructional materials used as teaching material because it can improve the character of environmental awareness in students. It can be concluded that PLH instructional materials used for teaching in primary schools, especially the fourth grade. His suggestion that EE teaching materials for fourth grade students that have been developed to be implemented in a learning activity to determine the extent of the advantages and disadvantages of these learning products.
\end{abstract}

Keywords: Teaching Materials, Character, Environmental Care.

\section{PENDAHULUAN}

Lingkungan merupkan bagian yang tidak terpisahkan dengan manusia. Lingkungan merupakan bagian integral dari kehidupan manusia. Terjaganya kelangsungan di sekitar manusia menjadikan kualitas hidup yang lebih baik. Oleh sebab itu manusia harus mampu untuk merawat dan menjaga kelangsungan lingkungan dengan baik. Namun yang terjadi saat ini adalah kualitas lingkungan hidup yang semakin merosot. Masalah lingkungan memang sudah terjadi sejak dahulu kala. Namun dampak secara lebih luas mulai kita rasakan pada abad melinium 20an saat ini. Hal tersebut selaras dengan perkembangan teknologi manusia.

Kerusakan alam yang terjadi juga berimbas pada kerusakan kehidpuan pada manusia. Kualitas alam mempengaruhi kualitas hidup manusia. Sebagai contoh asap (smoke) yang berasal dari asap kendaran bermotor, pabrik atau kebakaran hutan dapat menggangu sistem pernafasan manusia. Selain itu asap yang ada juga dapat menyebabkan pemanasan global. Pemanasan global adalah peningkatan suhu bumi. Dikutip dari Wikipedia bahwa suhu rata-rata global pada permukaan bumi telah meningkat $0.74 \pm$ $0.18^{\circ} \underline{\mathrm{C}}\left(1.33 \pm 0.32^{\circ} \underline{\mathrm{F}}\right)$ selama seratus tahun terakhir. Akibatnya banyak mempengaruhi hidup manusia seperti gunung es yang mencair sehingga tinggi permukaan laut meningat, curah hujan yang meningkat yang menyebabkan badai lebih sering terjadi, air tanah cepat menguap sehingga terjadi kekeringan, cuaca lebih sulit diprediksi dan cendrung lebih ekstrim sehingga menyebabkan kekeringan ekstrim atau curah hujan yang ekstrim. Serta masih banyak dampak lain dari pemanasan global yang 
disebabkan oleh aktifitas dan perkembangan teknologi manusia.

Beberapa hal pokok yang menyebabkan timbulnya masalah lingkungan antara lain adalah tingginya tingkat pertumbuhan penduduk, meningkatnya kualitas dan kuantitas limbah, adanya pencemaran lintas batas Negara (Tim Mata Kuliah PLH. 2014: 26). Meningkatnya jumlah pertumbuhan penduduk menyebabkan kepadatan manusia semakin meningkat sehingga aktifitas juga menignkat. Aktifitas manusia banyak sekali yang mempengaruhi lingkungan tanpa mempedulikan akibatnya. Sehingga miningkatnya jumlah penduduk juga menyebabkan meningkatnya aktifitas perusakan terhadap alam. Hal tersebut juga selaras dengan meningkatnya kuantitas dan kualitas limbah. Semakin banyak aktifitas dari manusia maka semakin banyak juga limbah yang dihasilkan baik secara kuantitas atau jumlahnya dan kualitas dari limbah tersebut. Kondisi di atas menunjukan bahwa kepedulian manusia terhadap lingkungan berada pada tahap yang mengkawatirkan. Kepedulian manusia terhadap lingkungan perlu ditingkatkan. Sehingga masalah-salah seperti yang dikemukakan di atas tidak terjadi lagi. Untuk itu perlu adanya peran pendidikan dalam hal ini. Pendidikan dituntut untuk bisa menanamkan karakter peduli lingkungan sejak atau sedari dini mungkin. Keluarga dan sekolah sebagai tempat anak sejak dini diajarkan tentang nilai-nilai kepedulian harus dapat mengajarkan pentingnya menjaga lingkungan.

Sejak dini anak atau siswa di sekolah perlu dikenalkan dengan krisis lingkungan, dampak dari kerusakan lingkungan dan cara mencintai lingkungan sehingga karakter peduli terhadap lingkungan dapat tumbuh pada diri anak. Pengajaran tersebut dapat dilakukan dan diintegrasikan pada mata pelajaran yang ada. Hal tersebut berdasarkan surat keputusan bersama Mentri Lingkungan Hidup dan Mentri Pendidikan Nasional No. Kep.07/MenLH/06/2005 dan N0. 05/VI/KB/2005 tentang pembinan dan pengembangan pendidikan lingkungan hidup.

Dari penjelasan di atas maka pendidikan memegang peran yang penting dalam perke bangan suatu bangsa. Dengan pendidikan diharapkan suatu bangsa berkembang menjadi bangsa yang bermartabat. Bermartabat adalah mempunyai martabat, sementara martabat dalam KBBI (2013) adalah tingkat harkat kemanusiaan, harga diri. Sebuah bangsa dikatakan bermartabat ketika manusai pada bangsa itu sendiri mampu untuk menunjukan perilaku atau sikap yang tertanam nilai-nilai kemanusia. Peduli pada sesama manusia, pada hewan, dan pada lingkungan merupakan beberapa bentuk dari harkat kemanusiaan.

Tercapainya tujuan pendidikan tidak hanya dilihat dari perkembangan pengetahuan atau kognitif peserta didik. Namun juga dilihat dari perkembangan afektif atau sikap peserta didik terhadap lingkungan. Hal diatas sesuai dengan fungsi pendidikan yang jelas dituangkan dalam Undang-Undang Republik Indonesia Nomor 20 Tahun 2003, pasal 3 yang menyebutkan bahwa.

"Pendidikan nasional berfungsi mengembangkan kemampuan dan membentuk watak serta peradaban bangsa yang bermartabat dalam rangka mencerdaskan kehidupan bangsa, bertujuan untuk berkembangnya potensi peserta didik agar menjadi manusia yang beriman dan bertaqwa kepada Tuhan Yang Maha Esa, berakhlak mulia, sehat, berilmu, cakap, kreatif, mandiri, dan menjadi warga negara yang demokratis serta bertanggung jawab. (Sisdiknas No 20 tahun 2003)". 
UU RI No. 20 pasal 3 menjelaskan bahwa tujuan pendidikan nasional yaitu mengembangkan potensi peserta didik. Potensi peserta didik yang dimaksud adalah agar peserta didik tumbuh menjadi manusia yang beriman, bertaqwa dan berakhlak mulia. Berakhlak mulia adalah sikap untuk berprilaku baik. Sikap peduli terhadap segala sesuatu yang ada lingkungannya. Oleh sebab itu pendidikan harus diselenggarakan dengan baik sehingga tujuan pendidikan dapat tercapai. Melalui pendidikan diharapkan bangsa Indonesia dapat berkembang menjadi bangsa yang bermartabat, dengan manusianya yang cerdas dan peduli terhadap lingkungannya.

Namun kondisi pendidikan di Sekolah khusunya sekolah dasar belum mampu menumbuhkan karakter peduli lingkungan pada siswa. Dari hasil pengamatan yang dilakukan oleh penulis, diperoleh data yang menunjukan bahwa prilaku siswa yang menunjukan karakter peduli terhadap lingkungan masih kurang. Berikut ini disajikan tabel hasil observasi perilaku kepedulian terhadap lingkungan siswa kelas IV SD Sendangmulyo 03 Semarang.

Dari data pada tabel 1 terlihat bahwa sebagian besar siswa masih kurang memiliki perilaku atau karakter peduli terhadap lingkungan. Selanjutnya dari hasil wawancara yang dilakukan oleh peneliti dengan Ibu Puji Ningtyas, S.Pd guru SD N Sendangmulyo 03 Semarang. Diketahui bahwa guru kurang terfokus menanamkan sikap peduli terhadap lingkungan, karena lebih terfokus pada penanaman ilmu pengetahuan siswa. Hal tersebut juga dikarenakan guru tidak mempunyai buku pedoman yang dapat digunakan guru untuk membantu dalam menamankan karakter peduli lingkungan.

Tabel 1.
Observasi Perilaku Kepedulian Lingkungan Siswa Kelas IV SD N Sendangmulyo 03 Semarang

\begin{tabular}{|c|c|c|c|c|}
\hline No & $\begin{array}{c}\text { Aktifitas } \\
\text { Siswa }\end{array}$ & $\begin{array}{l}\text { Siswa } \\
\text { Peduli }\end{array}$ & $\begin{array}{l}\text { Seluruh } \\
\text { Siswa }\end{array}$ & $\begin{array}{c}\text { Present } \\
\text { ase } \%\end{array}$ \\
\hline 1 & $\begin{array}{l}\text { Mematikan } \\
\text { Lampu yang } \\
\text { tidak } \\
\text { digunakan }\end{array}$ & 15 & 32 & $45 \%$ \\
\hline 2 & $\begin{array}{l}\text { Membuang } \\
\text { sampah pada } \\
\text { tempatnya }\end{array}$ & 16 & 32 & $50 \%$ \\
\hline 3 & $\begin{array}{l}\text { Merawat } \\
\text { tanaman } \\
\text { sekolah }\end{array}$ & 9 & 32 & $15 \%$ \\
\hline 4 & $\begin{array}{l}\text { Memisahkan } \\
\text { sampah } \\
\text { organik dan } \\
\text { anorganik }\end{array}$ & 5 & 32 & $20 \%$ \\
\hline
\end{tabular}

Kondisi menunjukan terjadinya ketimpangan antara harapan dan kondisi nyata. Pendidikan diharapkan selain juga menumbuh kembangkan pengetahuan siswa juga menumbuhkan karakter peduli terhadap lingkungan. Namun kondisi nyata yang ada di lapangan menunjukan bahwa pendidikan tidak dapat sepenuhnya menanamkan nilai karakter peduli terhadap lingkungan. Kondisi sedemikian selanjutnya disebut sebagai masalah. Masalah adalah ketimpangan antara harapan dan keadaan.

Masalah harus segera diatasi dan diselesaikan. Oleh sebab itu dalam hal ini penulis memberikan solusi sebagai pemecahan masalah adalah mengembangkan bahan ajar PLH (Pendidikan Lingkungan Hidup). Dengan adanya bahan ajar PLH diharapkan mampu menumbuhkan karakter siswa untuk peduli terhadap lingkungan. Menurut Panner (2001) dalam Prastowo (2012: 17) bahan ajar adalah bahan-bahan atau materi pelajaran yang disusun secara 
sistematis, yang digunakan guru dan peserta didik dalam proses pembelajaran. Bahan ajar adalah materi yang telah tersusun secara sistematis. Materi yang terdapat dalam bahan ajar digunakan oleh guru dan siswa dalam proses pembelajaran.

Bahan ajar yang terdapat saat ini tidak banyak yang dirangcang untuk menanamkan karakter peduli terhadap lingkungan. Akibatnya karakter kepedulian lingkungan siswa masih rendah. Diperlukan inovasi, kreatifitas dalam membuat bahan ajar yang dapat menanamkan karakter. Prastowo (2012: 19) menyampaikan bahwa mutu pembelajaran menjadi rendah ketika pendidik hanya terpaku pada bahan-bahan ajar yang konvensioanl tanpa ada kreatifitas untuk mengembangkan bahan ajar tersebut secara inovatif. Pendapat tersebut menekankan bahwa jika tidak ada inovasi dan kreatifitas dalam membuat bahan ajar maka mutu pembelajaran menjadi rendah. Termasuk proses penanaman karakter peduli lingkungan akan menjadi rendah. Sehingga diperlukan kreatifitas dalam pembuaatan bahan ajar. Salah satunya yaitu membuat bahan ajar PLH yang diharapkan yang bertujuan untuk menumbuhkan karakter peduli lingkungan pada siswa.

Pendidikan lingkungan hidup mempelajari tentang lingkungan khsusunya tentang pencemaran lingkungan, kerusakan alam, sumber daya alam dan konservasi. Pendidikan lingkungan hidup (PLH) merupakan upaya mengubah prilaku dan sikap yang dilakukan oleh berbagai pihak atau elemen masyarakat yang bertujuan untuk meningkatkan pengetahuan, keterampilan, dan kesadaran masyarakat tentang nilai-nilai lingkungan dan isu permasalahan lingkungan yang akhirnya dapat menggerakkan masyarakat untuk dapat berperan aktif dalam upaya pelestarian dan keselamatan lingkungan untuk kepentingan generasi sekarang dan yang akan datang. (Tim Penyususn PLH. 2010 :2).

Bahan ajar PLH selanjunya diharapkan mampu menggerakkan siswa untuk mempunyai pengetahuan, keteramapilan dan kesadaran tentang kepedulian terhadap lingkungan. Melalui bahan ajar PLH proses pembelajaran dapat terarah untuk membekali diri siswa menjadi manusia yang peduli terhadap lingkungan. Kepedulian tersebut selanjutnya tumbuh menjadi karakter.

KBBI (2013) menyebutkan bahwa karakter ialah tabiat; sifat-sifat kejiwaan, akhlak atau budi pekerti yang membedakan seseorang dengan yang lain, watak. Berkarakter diartikan sebagai mempunyai sifat-sifat yang khusus. Karakter peduli pada lingkungan adalah sifat-sifat peduli terhadap lingkungan. Peduli lingkungan dapat ditunjukan dengan sikap-sikap pelestarian lingkungan dan menjaga lingkungan. Karakter dibentuk dengan melalui pendidikan karakter. Pendidikan karakter bertujuan untuk membentuk pribadi anak, supaya menjadi manusia yang baik, warga masyarakat dan warga negara yang baik (Tim IKIP PGRI Semarang :11).

Penelitian tetang penggunaan bahan ajar telah banyak dilakukan, salah satunya yaitu penelitian dari Ilmiwan, dkk (2013) dengan judul pengaruh penerapan bahan ajar bermuatan nilai nilai karakter dalam model pembelajaranlangsung terhadap hasil belajar siswa kelas XI SMA N 1 Bukittinggi. Dari penelitian tersebut disimpulkan bahwa hasil dari nilai rata-rata dari kelas eksperimen lebih tinggi dari pada kelas kontrol. Penerapan bahan ajar bermuatan nilai-nilai karakter memberikan efek pada hasil belajar yang siknifikan. 
Bahan ajar PLH telah ada sebelumnya, namun bahan ajar bahan ajar tersebut belum terdapat nilai-nilai karakter yang nampak jelas dipaparkan dalam bentuk gambar, cerita yang menarik. Oleh sebab itu bahan ajar PLH berbasis karakter dikembangkan yang bertujuan untuk menumbuhkankan karakter peduli lingkungan pada siswa. Selanjutnya berdasarkan pembahasan di atas maka peneliti berusaha untuk melakukan penelitian berupa pengembangan bahan ajar. Penelitian ini selanjutnya berjudul "Pengembangan Bahan Ajar Pendidikan Lingkungan Hidup Untuk Menumbuhkan Nilai Karakter Peduli Lingkungan Pada Siswa Kelas IV Sekolah Dasar".

Menurut Pannen (dalam Andi Prastowo, 2012: 17), mengungkapkan bahwa bahan ajar adalah bahan-bahan atau materi pelajaran yang disusun secara sistematis, yang digunakan guru dan peserta didik dalam proses pembelajaran. Sedangkan menurut National Centre for Competency Based Training (dalam Andi Prastowo, 2012:16) bahan ajar adalah segala bentuk yang digunakan untuk membantu guru atau instruktur dalam melaksanakan proses pembelajaran di kelas.

Berdasarkan beberapa pandangan mengenai pengertian bahan ajar tersebut, dapat kita pahami bahwa bahan ajar merupakan segala bahan (baik informasi, alat, maupun teks) yang disusun secara sistematis, yang menampilkan sosok utuh dari kompetensi yang akan dikuasai peserta didik dan digunakan dalam proses pembelajaran dengan tujuan perencanaan dan penelaahan implementasi pembelajaran. Misalnya, buku pelajaran, modul, handout, LKS, model atau maket, bahan ajar audio, bahan ajar interaktif, dan sebaginya (Andi Prastowo, 2012:17).
Menurut Nana Supriatna dkk (2007: 3), pendidikan mengandung pengertian suatu perbuatan yang disengaja untuk menjadikan manusia memiliki kualitas yang lebih baik. Dari tidak tahu menjadi tahu, dari tidak mengerti menjadi mengerti dan sebagainya.

Definisi pendidikan dalam buku Pedoman Pendidikan Karakter IKIP PGRI SEMARANG (sekarang Universitas PGRI Semarang), sebagai berikut. Pendidikan adalah suatu proses enkulturasi, berfungsi mewariskan nilai-niai dan prestasi masa lalu ke generasi mendatang. Nilai-nilai dan prestasi itu merupakan kebanggaan bangsa dan menjadikan bangsa itu dikenal oleh bangsa-bangsa lain. Selain mewariskan, pendidikan juga memiliki fungsintuk mengembangkan nilai-nilai budaya dan prestasi masa lalu itu menjadi nilai-nilai budaya bangsa yang sesuai dengan kehidupan masa kini dan masa yang akan datang, serta mengembangkan prestasi baru yang menjadi karakter baru bangsa. Oleh karena itu, pendidikan budaya dan karakter bangsa merupakan inti dari suatu proses pendidikan.

Pendidikan lingkungan hidup (selanjutnya disingkat dengan PLH) adalah mengubah pandangan dan perilaku seseorang terhadap lingkungan. Orang tadinya masa bodoh dengan lingkungan diharapkan berubah menjadi peduli dengan lingkungannya. Orang tadinya hanya menjadi pemerhati (Sudjoko, 2011: 1.1).

Dalam buku ajar MKU PLH Universitas Negeri Semarang (TIM Mata Kuliah PLH, 2014: 1), PLH merupakan upaya mengubah perilaku dan sikap yang dilakukan oleh berbagai pihak atau elemen masyarakat yang bertujuan untuk meningkatkan pengetahuan, ketrampilan dan kesadaran masyarakat tentang nilai-nilai lingkungan dan isu 
permasalahan lingkungan yang pada akhirnya dapat menggerakkan masyarakat untuk berperan aktif dalam upaya pelestarian dan keselamatan lingkungan untuk kepentingan generasi sekarang dan yang akan datang. Pendidikan lingkungan hidup mempelajari permasalahan lingkungan khususnya masalah dan pengelolaan pencemaran, kerusakan lingkungan serta sumberdaya dan konservasi.

Menurut Thomas Lickona (dalam Agus Wibowo, 2012: 32), karakter merupakan sifat alami seseorang dalam merespon sesuatu secara bermoral. Pengertian yang dikemukakan Lickona ini, mirip dengan apa yang diungkapkan oleh Aristoteles, bahwa karakter itu erat kaitannya dengan "habit" atau kebiasaan yang terus menerus dilakukan.

Pengertian karakter dalam buku Pedoman Pendidikan Karakter IKIP PGRI SEMARANG (sekarang Universitas PGRI Semarang) adalah "bawaan, hati, jiwa, kepribadian, budi pekerti, perilaku, personalitas, sifat, tabiat, tempramen, watak". Sedangkan menurut Simon Philips dalam buku Pendidikan Karakter menjawab tantangan krisis multidimensional (2011: 10), karakter adalah kumpulan tata nilai yang mengacu pada suatu sistem, yang melandasi pemikiran, sikap, dan perilaku yang ditampilkan.

Sedangkan menurut Kemendiknas (dalam Agus Wibowo, 2010:35), karakter adalah tabiat akhlak, atau kepribadian seseorang yang terbentuk dari hasil internalisasi berbagai kebijakan (virtues) yang diyakini dan digunakan sebagai landasan untuk cara pandang, berpikir, bersikap, dan bertindak.

Deskripsi nilai karakter peduli lingkungan yaitu sikap dan tindakan yang selalu berupaya mencegah kerusakan pada lingkungan alam di sekitarnya, dan mengembangkan upaya-upaya untuk memperbaiki kerusakan alam yang sudah terjadi (dalam buku Pedoman Pendidikan Karakter IKIP PGRI SEMARANG:70).

Banyak temuan-temuan para peneliti terdahulu yang membuktikan bahwa penggunaan modul sebagai sarana pembelajaran memiliki nilai efektivitas yang tinggi, seperti penelitian yang dilakukan oleh Nurani dkk (2014) dalam penelitiannya tentang Pengembangan Modul Pendidikan Lingkungan Hidup (PLH) Berbasis Karakter untuk Menumbuhkan Wawasan dan Karakter Peduli Lingkungan menunjukkan bahwa modul PLH berbasis karakter efektif digunakan untuk mengajak siswa peduli terhadap kondisi di sekitarnya. Semntara itu Ilmiwan dkk (2013) dalam penelitiaannya yang tentang pengaruh penerapan bahan ajar bermuatan nilai-nilai karakter dalam model pembelajaran langsung terhadap hasil belajar siswa kelas XI SMAN 1 Bukittinggi menunjukkan bahwa bahan ajar berhasil meningkatkan karakter peduli lingkungan kepada siswa dan sangat layak digunakan menjadi bahan ajar.

\section{METODE PENELITIAN}

Metode penelitian yang digunakan dalam penelitian ini adalah Penelitian dan Pengembangan (Reseacrch and Development/R\&D). Pemilihan metode penelitian tersebut dikarenakan peneliti hendak mengembangkan bahan ajar. Hal ini sesuai dengan pendapat dari Borg dan Gall (1988) dalam Sugiyono (2009: 4) yang menyatakan bahwa, penelitian dan pengembangan (research and development) merupakan metode penelitian yang digunakan untuk mengembangkan atau 
memvalidasi produk-produk yang digunakan dalam pendidikan dan pembelajaran (Zainal, 2014).

Menurut Gall and Borg (Putra 2015: 84) Research and Development dalam pendidikan adalah sebuah model pengembangan berbasis kriteria dimana temuan penelitian digunakan untuk merancang produk dan prosedur baru, yang kemudian secara sistematis diuji di lapangan, dievaluasi, dan disempurnakan sampai memenuhi kriteria tertentu yaitu efektivitas, dan berkulitas.

Menurut National Science Board dalam "Research And Development: Essential Foundation For U.S Competitiveness in A Global Economy" (2008: Endnotes) dalam Putra (2015: 70).

Penelitian didefinisikan sebagai studi sistematis terhadap pengetahuan ilmiah yang lengkap atau pemahaman tentang subjek yang diteliti. Penelitian ini diklasifikasikan sebagai dasar atau terapan sesuai dengan tujuan sponsor. Pengembangan didefinisikan sebagai aplikasi sistematis dari pengetahuan atau pemahaman, diarahkan pada produksi bahan yang bermanfaat, perangkat, dan sistem atau metode, termasuk desain, pengembangan dan peningkatan prioritas, serta proses baru untuk memenuhi persyaratan tertentu.

Secara sederhana R\&D bisa didefinisikan sebagai metode penelitian yang secara sengaja, sistematis, bertujuan/diarahkan untuk mencari temukan, merumuskan, memperbaiki, mengembangkan, menghasilkan, menguji keefektifan produk, model, metode/strategi/cara, jasa prosedur tertentu yang lebih unggul, baru, efektif, efisien, produktif, dan bermakna (Putra, 2015: 67)
Riset dan pengembangan merupakan suatu proses pengembangan perangkat pendidikan yang dilakukan melalui serangkaian riset yang menggunakan berbagai metode dalam suatu siklus yang melewati berbagai tahapan (Amile dan Reenes dalam Ali dan Asrori, 2014: 105).

Berdasarkan definisi di atas dapat disimpulkan bahwa Research and Development atau penelitian dan pengembangan adalah metode penelitian yang digunakan untuk menghasilkan dan mengembangkan produk tertentu dengan inovasi baru yang didahului oleh tahap pengujian atau validasi.

Penulis berusaha untuk mengembangkan sebuah bahan ajar. Untuk itu diperlukan validasi terhadap bahan ajar tersebut. R\&D merupakan metode penelitian yang dapat digunakan untuk memvalidasi bahan ajar tersebut. Hal tersebut sesuai ungkapan Borg dan Gall di awal paragraf tadi yang menyatakan bahwa R\&D juga digunakan untuk memvalidasi produk yang dikembangkan.

Dalam hal ini penulis mengembangkan sebuah bahan ajar. Merupakan inovasi dari bahan ajar terdahulu. Pengembangan bahan ajar ini diharapkan membawa kebaharuan, keunggulan, efektifitas, efisiensi dan produktifitas. Alasan tersebutlah yang juga mendasari penulis menggunakan metode R\&D. Hal ini sesuai dengan pendapat dari Putra (2015: 67) R\&D memang diarahkan untuk mencari temukan kebaharuan dan keunggulan dalam rangka efektifitas, efisiensi, dan produktifitas.

Selanjutnya, prosedur dalam penelitian pengembangan ini menerapkan prosedur ADDIE . Model ini, terdiri dari sepuluh tahap utama, yaitu (A)nalysis, (D)esain, (D)evelopment, (I)mplementation, dan 
(E)valuation (Pribadi, 2010:125). Metode penelitian dan pengembangan adalah metode yang digunakan untuk menghasilkan produk tertentu.

\section{Analysis}

Analisis merupakan langkah atau tahap pertama dalam prosedur ADDIE. Analisis digunakan guna menemukan ide, dan tujuan yang hendak dicapai. Analisis dilakukan penulis mengumpulkan informasi melalui kajian pustaka, pengamatan dan wawancara. Dalam prosesnya penulis terfokus untuk menemukan potensi dan masalah yang terdapat dalam pendidikan di Indonesia.

Pertama penulis mencoba untuk menganalisis potensi, penulis melihat bahan ajar yang sudah ada namun belum memuat nilai karakter peduli lingkungan juga masalah yang ada di negara dimuat oleh TIM Mata Kuliah PLH UNNES bahwa timbulnya masalah lingkungan antara lain tingginya tingkat pertumbuhan penduduk, meningkatnya kualitas dan kuantitas limbah dan adanya pencemaran lintas batas Negara.

Kedua penulis menganalisis masalah yang terjadi dalam pendidikan. Dari hasil wawancara dengan Ibu Pujiningtyas, S.Pd guru Kelas IV SD N Sendangmulyo 03 Semarang disampaikan bahwa guru kurang terfokus menanamkan sikap peduli terhadap lingkungan, karena lebih terfokus pada penanaman ilmu pengetahuan siswa. Hal tersebut juga dikarenakan guru tidak mempunyai buku pedoman yang dapat digunakan guru untuk membantu dalam menanamkan karakter peduli lingkungan. Juga karakter peduli lingkungan siswa masih rendah.

Selanjutnya yaitu analisis pada kajian pustaka, yaitu teori-teori yang dapat digunakan untuk melandasi penyelesaian masalah tersebut, diantaranya yaitu definisi bahan ajar. Definisi PLH, penelitian terdahulu tentang penggunaan bahan ajar. Dari potensi, masalah dan kajian pustaka yang penulis kumpulkan, maka dapat digunakan sebagai landasan penulis mengembangkan bahan ajar PLH dalam pembelajaran di Sekolah Dasar.

\section{Desain}

Hasil analisis diatas dapat digunakan penulis guna merancang sebuah bahan ajar. Alternatif desain bahan ajar yang dikembangkan oleh peneliti adalah sebuah bahan ajar yang disebut bahan ajar PLH. Bahan ajar tersebut didesain guna meningkatkan karakter peduli lingkungan siswa. Lebih lanjut bahan ajar tersebut sekaligus menjawab keinginan guru untuk dapat memperoleh bahan ajar. Sekaligus bahan ajar ini didesain untuk memberikan kemudahan kepada siswa dalam memahami materi-materi pembelajaran.

Bahan ajar PLH merupakan bahan ajar untuk menumbuhkan karakter peduli lingkungan siswa. Bahan ajar ini berbentuk buku. Materi dalam bahan ajar ini berisikan materi-materi pembelajaran dan nilai-nilai karakter peduli lingkungan, sehingga meningkatkan minat siswa untuk dapat memahami materi pelajaran dan menumbuhkan karakter peduli lingkungan siswa.

\section{Development (pengembangan)}

Produk bahan ajar PLH dibuat berdasarkan hasil analisis terhadap potensi, masalah di sekolah, kajian pustaka, analisis terhadap kompetensi materi, dan analisis terhadap tujuan intruksional. Dari dasar analisis tersebut selanjutnya disusun atau dirumuskan dalam bentuk desain bahan ajar 
PLH. Untuk selanjutnya menjadi dasar pengembangan bahan ajar PLH.

Langkah-langkah dalam pembuatan

bahan ajar PLH, yaitu:

a. Membuat bahan ajar PLH

Langkah-langkah yang dilakukan peneliti untuk membuat bahan ajar PLH terdiri dari beberapa langkah, diantaranya: 1) menentukan materi atau isi buku, 2) menggambar dan mendesain cover, 3) menulis isi buku, 4) memasukan detail gambar dan nilai-nilai karakter dalam bahan ajar, 5) mencetak bahan ajar PLH.

b. Pembimbingan dan Penilaian dengan Validator.

Bahan ajar PLH yang telah dibuat, selanjutnya dibimbingkan dan dinilai oleh dosen pembimbing. Dalam prosesnya bahan ajar PLH akan mendapatkan saran-saran oleh dosen pembimbing untuk diperbaiki, atau dinyatakan layak. Jika bahan ajar PLH telah dinyatakan layak, maka dapat dilanjutkan untuk divalidasi oleh ahli media dan ahli materi.

c. Validasi oleh Ahli Media dan Ahli Materi.

Ahli media adalah seseorang yang berkompentensi dalam bidang media pembelajaran, sementara ahli materi adalah seseorang yang mempunyai kompetensi dalam bidang materi pembelajaran. Setelah bahan ajar PLH dinyatakan layak oleh dosen pembimbing, maka bahan ajar tersebut selanjutnya dilakukan validasi oleh validator yaitu ahli media dan ahli materi.

Ahli media akan menilai bahan ajar PLH dengan cara memberikan nilai sesuai dengan rubrik penilaian, begitupun dengan ahli materi akan memberikan nilai sesuai dengan rubrik penilaian.
Selanjutnya kedua ahli tersebut juga memberikan saran untuk perbaikan bahan ajar. Saran dari kedua ahli tersebut harus ditindak lanjuti, sehingga bahan ajar dinyatakan layak.

\section{Implementation}

Penerapan bahan ajar PLH dilaksanakan di kelas IV SD Negeri Sendangmulyo 03 Semarang dengan siswa pembelajaran dengan menggunaka bahan ajar PLH. Lebih lanjut penerapan bahan ajar ini juga ditujukan untuk menumbuhkan nilai karakter peduli lingkungan pada siswa siswa. Sebelum diujicobakan bahan ajar sudah divalidasi terlebih dahulu. Uji validasi yang dilakukan oleh peneliti meliputi validasi ahli media pembelajaran dan validasi ahli materi pembelajaran.

Setelah media tersebut divalidasi oleh ahli media dan ahli materi. Langkah selanjutnya adalah merevisi jika terdapat kekurangan yang perlu diperbaiki.

Pada tahapan implementasi, bertujuan untuk mendapatkan desain bahan ajar PLH yang valid dan baik. Revisi produk dilakukan oleh peneliti secara berkala apabila desain belum mencapai tingkatan valid yang diharapkan. Pihak yang berperan penting pada tahap ini adalah ahli media dan ahli materi pembelajaran yang menentukan apakah desain perlu direvisi atau sudah sesuai. Bahan ajar PLH yang sudah direvisi atau diperbaiki selanjutnya diterapkan pada kelas uji coba.

\section{Evaluation}

Evaluasi yang dilakukan untuk bahan ajar PLH bertujuan menyempurnakan produk setelah melalui tahap implementasi. Evaluasi meliputi perbaikan produk yang didapat dari saran pada angket yang diberikan kepada ahli media dan ahli materi (guru kelas), 
selanjutnya peneliti dapat memperbaikinya. Efektif atau tidaknya bahan ajar PLH serta minat siswa terhadap bahan tersebut dapat dilihat dari angket tanggapan siswa dan lembar observasi karakter siswa untuk mengetahui tumbuhnya karakter kepedulian lingkungan pada siswa.

Pada penelitian pengembangan, subjek penelitian kualitas Bahan Ajar PLH kelas IV sekolah dasar adalah tiga pakar ahli media dan materi serta dari respon siswa kelas IV sekolah dasar.

\section{HASIL DAN PEMBAHASAN}

Penelitian ini adalah penelitian pengembangan (Research and Development) dengan menghasilkan produk berupa media pembelajaran yang akan di ujicoba pada ujicoba secara terbatas. Pengembangan dilaksanakan setelah melakukan observasi terlebih dahulu, untuk mengetahui karakter kepedulian lingkungan siswa di kelas IV. Observasi berlangsung dengan wawancara tidak terstruktur kepada guru dan angket tanggapan siswa, wawancara tidak terstruktur ini hanya memberikan pertanyaan yang tanpa mempersiapkan jawaban dan angket tanggapan siswa berisi beberapa pertanyaan kepada siswa dengan jawaban iya atau tidak. Jadi dalam observasi ini hanya mendengarkan cerita yang diperoleh dari guru dan hasil angket tanggapan siswa, sedangkan untuk penelitian selanjutnya mengambil kesimpulan sendiri apa yang dihasilkan dari observasi yang dilakukan.

Pada observasi hanya mengambil sample 20 siswa. Sasaran dari pengembangan bahan ajar PLH ini adalah guru dan siswa kelas IV SD Sendangmulyo 03 Semarang dengan jumlah 20 siswa, yang berdasarkan hasil wawancara dengan guru kelas IV bahwa guru kurang terfokus menanamkan sikap peduli terhadap lingkungan karena lebih terfokus pada penanaman ilmu pengetahuan kepada siswa, guru tidak mempunyai buku pedoman yang digunakan guru untuk membantu dalam menanamkan karakter peduli lingkungan. Hal ini di ketahui juga dari hasil angket tanggapan siswa bahwa sebagian besar siswa masih kurang memiliki karakter peduli lingkungan.

Hasil wawancara dan tanggapan siswa, penelitian ini bermaksud menumbuhkan karakter peduli lingkungan siswa melalui bahan aja PLH. Prastowo (2012:19) mengatakan bahwa mutu pembelajaran menjadi rendah ketika pendidik hanya terpaku pada bahan-bahan ajar yang konvensional tanpa ada kreatifitas untuk mengembangkan bahan tersebut secara inovatif.

Penggunaan bahan ajar diperlukan guru dalam pembelajaran, karena bahan ajar merupakan bagian dari sumber belajar. Hal ini disampaikan Panner, bahan ajar adalah bahanbahan atau materi pelajaran yang disusun secara sistematis, yang digunakan guru dan peserta didik dalam proses pembelajaran. Maka dari itu perlu adanya pengembangan produk bahan ajar yang menarik agar siswa tertarik dan menumbuhkan karakter peduli lingkungan siswa.

Penelitian ini memilih mengembangkan bahan ajar PLH. Menurut TIM mata kuliah PLH UNNES, PLH merupakan upaya mengubah perilaku dan sikap yang dilakukan oleh berbagai pihak atau elemen masyarakat yang bertujuan untuk meningkatkan pengetahuan, ketrampilan dan kesadaran masyarakat tentang nilai-nilai lingkungan dan isu permasalahan lingkungan yang pada akhirnya dapat menggerakkan masyarakat untuk berperan aktif dalam upaya pelestarian dan keselamatan lingkungan untuk kepentingan generasi sekarang dan yang akan datang. 
Bahan ajar PLH selanjutnya dikembangkan berdasarkan analisis kesesuaian dengan prinsip-prinsip pendidikan lingkungan hidup. Selanjutnya didasarkan atas standar kompetensi dan kompetensi dasar. Serta dianalis sesuai dengan indikator yang dikembangkan dari kompetensi dasar. Hasil analisis kemudian digunakan peneliti untuk merancang desain dari bahan ajar PLH. Desain atau perancangan bahan ajar PLH meliputi beberapa hal diantaranya: Konsep desain dari bahan ajar PLH ini terdiri dari tujuh langkah yaitu: 1) Menentukan SK, KD, dan Indikator, 2) cover dan icon cover, 3) Merancang isi, 4) Meentukan materi, 5) menyusun bahan ajar, 6) menyisipkan karakter peduli lingkungan. Dari hasil rancangan konsep tersebut, selanjutnya bahan ajar dikembangan dengan memperhatikan konsep, materi, sistematika penulisan, dan penyisipan karakter sehingga tercipta bahan yang menarik bagi siswa dan dapat membantu proses belajar mengajar menjadi lebih maksimal.

Dalam pengembangannya, bahan ajar perlu divalidasi oleh ahli sebelum diuji cobakan untuk mengetahui kelayakannya. Validasi terdiri dari dua pakar yaitu validasi media dan validasi materi. Setelah bahan ajar divalidasi dan dinyatakan layak digunakan dalam proses pembelajaran. Kemudian bahan ajar PLH diujicobakan di sekolah dasar untuk melihat respon dari siswa. Pengujian ini dilakukan di SD N Sendangmulyo 03 Semarang. Pengujian dilakukan uji satu kelas yaitu kepada siswa kelas IV SD N Sendangmulyo 03 Semarang.

Hasil validasi dengan ahli media, diperoleh data sebagai berikut 1) pada validasi I tingkat keidealan bahan ajar PLH adalah 90\% dengan masukan dari Ahli Media yaitu gambar di dalam bahan ajar bisa disesuaikan dengan kebutuhan tidak terlalu besar atau terlalu kecil dan bahan ajar sudah layak diujicobakan di lapangan tanpa ada revisi. Hasil validasi ahli materi, diperoleh data sebagai berikut 1) pada validasi I tingkat keidealan bahan ajar PLH adalah 58\% dengan masukan dari ahli materi yaitu bahan ajar belum sistematis dan urut sesuai dengan kesesuaian bahan ajar sehingga harus ada beberapa revisi materi dan gambar serta kegiatan siswa. Oleh sebab itu dilakukan revisi dan validasi kedua, 2) pada validasi II tingkat keidealan bahan ajar PLH yang telah direvisi mencapai $71 \%$ dengan masukan dari ahli materi yaitu beberapa maeri yang diulas bisa lebih dirampingkan dan beberapa gambar penyakit akibat bakteri atau virus ditambahkan keterangan. Oleh sebab itu dilakukan revisi dan validasi ketiga, 2) pada validasi III tingkat keidealan bahan ajar PLH yang telah direvisi mencapai $75 \%$. Sehingga bahan ajar sudah layak digunakan. Sementara hasil validasi ahli media dari guru, diperoleh data dimana tingkat keidealan bahan ajar PLH adalah $85 \%$. Sedangkan hasil validasi materi dari guru, diperoleh data dimana tingkat keidealan bahan ajar PLH adalah 95\% dengan komentar yaitu bahan ajar sudah baik dan tersusun secara sistematis dan dapat diujicobakan.

Setelah dilakukan validasi dan revisi bahan ajar maka didapatkan bahan ajar PLH yang layak digunakan untuk menumbuhkan karakter peduli lingkungan.Selanjutnya adalah uji coba soal pre test dan post test saat pembelajaran. Uji soal menggunakan rumus $N$-gain. Hasil analisis gain menunjukkan bahwa gain dengan kriteria tinggi atau interval gain $\geq 0,7$ sebanyak 22 siswa. Kriteria gain sedang atau interval gain $0,3 \leq \mathrm{g}<0,7$ sebanyak 12 siswa. Jadi secara keseluruhan 
penelitian ini menunjukkan gain dengan kriteria tinggi.

Berdasarkan hasil respon 34 siswa kelas IV SD N Sendangmulyo 03 Semarang terhadap bahan ajar diperoleh hasil nilai ratarata persentas respon siswa yaitu 99\%, ternyata pembelajaran yang memanfaatkan bahan ajar PLH dapat memudahkan pemahaman siswa, meningkatkan kemandirian belajar, memudahkan siswa, minat, dan keaktifan dalam proses pembelajaran. Hal ini sesuai dengan pendapat Pannen (dalam Andi Prastowo, 2012:17), mengungkapkan bahwa bahan ajar adalah bahan-bahan atau materi pelajaran yang disusun secara sistematis, yang digunakan guru dan peserta didik dalam proses pembelajaran.

Nilai karakter peduli lingkungan yaitu sikap dan tindakan yang selalu berupaya mencegah kerusakan pada lingkungan alam di sekitarnya, dan mengembangkan upaya-upaya untuk memperbaiki kerusakan alam yang sudah terjadi (dalam buku Pedoman Pendidikan Karakter IKIP PGRI Semarang: 70). Hasil observasi yang dilakukan oleh peneliti dan ahli diperoleh skor rata-rata 19 dengan kriteria "Amat Baik" dan skor ratarata 18,9 dengan kriteria “Amat Baik”. Dasar bagi pengembangan bahan ajar pendidikan lingkungan hidup yaitu teori belajar behavioristik atau aliran tingkh laku, belajar diartikan sebagai proses perubahan tingkah laku sebagai akibat dari interaksi antara stimulus dan respons. Belajar menurut psikologi behavioristik adalah suatu kontrol instrumental yang berasal dari lingkungan. Belajar tidaknya seseorang tergantung pada faktor-faktor kondisional yang diberikn lingkungan. Dengan demikian, perubahan perilaku juga merupakan hasil belajar seseorang terhadap lingkungannya dengan belajar menggunakan bahan ajar PLH.

\section{SIMPULAN}

Berdasarkan hasil penelitian dan pengembangan bahan ajar PLH yang telah dilakukan di SD N Sendangmulyo 03 Semarang, diperoleh data yang menunjukan bahwa bahan ajar PLH layak digunakan. Data-data tersebut diperoleh dari validasi oleh ahli materi dan media, data dari tanggapan atau respon siswa, dan observasi karakter peduli lingkungan siswa. Sehingga dapat sisimpulkan secara umum bahwa bahan ajar PLH layak digunakan sebagai bahan ajar di kelas IV Sekolah Dasar. Setelah bahan ajar PLH dinyatakan layak sebagai bahan ajar bagi siswa kelas IV Sekolah Dasar maka bahan ajar PLH dapat dipasarkan dan menjadi bahan ajar yang menumbuhkan karakter peduli lingkungan siswa.

Penelitian pengembangan yang dilakukan memiliki keterbatasan yaitu belum dilakukannya analisis keefektifan bahan ajar PLH secara mendalam dalam proses pembelajaran di kelas. Slanjutnya keterbatasan lainnya yaitu bahan ajar PLH hanya diberi penilaian oleh 3 reviewer yaitu ahli bahan ajar Bapak Singgih Adhi P, SSn., M.Pd, ahli materi Ibu Filia Arthaprima, S.Pd., M.Pd dan ahli media sekaligus ahli materi dari guru yaitu Ibu Puji Ningtyas, S.Pd serta hanya diuji cobakan pada siswa di 1 sekolah yaitu SD N Sendangmulyo 03 Semarang. 


\section{DAFTAR PUSTAKA}

Ali, Mohammad dan Asrori, Mohammad. 2014. METODOLOGI DAN APLIKASI RISET PENDIDIKAN. Jakarta. Cahaya Prima Sentosa.

Departemen Pendidikan Nasional. 2013. Kamus Besar bahasa Indonesia. Jakarta: PT Gramedia Pustaka Utama.

Ilmiwan, et al. 2013. "Pengaruh Penerapan Bahan Ajar Bermuatan Nilai Nilai Karakter Dalam Model Pembelajaranlangsung Terhadap Hasil Belajar Siswa Kelas xi Sman 1 Bukittinggi" Jurnal Pillar of Physics of Education Volume 2 No. Halaman 153-160. http://fisika.fmipa.unp.ac.id/wp-content/uploads/2014/12/File5.pdf.

Nurani, dkk. 2014. "Pengembangan Modul Pendidikan Lingkungan Hidup (PLH) Berbasis Karakter untuk Menumbuhkan Wawasan dan Karakter Peduli Lingkungan" Unnes Journal of Biology Education 3 file:///C:/Users/User\%20pc/Downloads/4155-8500-2-PB.pdf.

(2014)

Prastowo, Andi. 2012. Panduan Kreatif Membuat Bahan Ajar Inovatif. Jogjakarta: Diva Press.

Pribadi, Benny A. 2010. Model Desain Sistem Pembelajaran. Jakarta : Dian Rakyat.

Putra. Nusa. 2012. Research and Development. Jakarta : PT Grafindo Persada

Sudjoko. 2011. Pendidikan Lingkungan Hidup: Jakarta Alfabeta.

Supriatna, Nana, dkk. 2007. PENDIDIKAN IPS SD. Bandung: UPI PRESS.

Tim IKIP PGRI Semarang. 2011. Pedoman Pendidikan Karakter. Semarang: IKIP PRGRI Semarang.

TIM MKU PLH. 2010. Pendidikan Lingkungan Hidup. Semarang: Universitas Negri Semarang.

Semarang.

2014. Pendidikan Lingkungan Hidup. Semarang: Universitas Negri

Undang-Undang Republik Indonesia Nomor 20 tahun 2003 tentang Sistem Pendidikan Nasional. Jakarta: PT. Rineka Cipta

Wibowo, Agus. 2012. Pendidikan Karakter. Yogyakarta: Pustaka Pelajar.

Wikipedia. Pemanasan Global. https://id.wikipedia.org/wiki/Pemanasan_global. Diakses pada 25 Juni 2016.

Zainal, Arifin. 2014. Penelitian Pendidikan. Bandung: PT Remaja Rosdakarya. 